\title{
LIVES IN DARK: A STUDY OF COMMERCIAL CHILD SEX WORKERS IN KARACHI
}

\author{
Aliyah Ali Bilgrami*
}

\begin{abstract}
Child prostitution is defined as a youngster is given cash or products by the culprit party previously or later than sexual relation, in any age children are liable to prostitution. The powerless and frequently misled youngster, there might be few or no elective alternatives. Unfortunately, children may regularly persuade themselves that they have settled on a free decision, instead of recognizing that their own lives are not in their control. Rising destitution is driving a developing figure of family unit to offer kids, along with girl child specifically get involved in sex work. The research study is basically qualitative. Recent situation analyses and reports shows acceleration in different security issues of children for example camel race, and the sexual commercial exploitation of children and juvenile justice. These incorporate physical and mental handicap children, from ethnic minorities and minimized populaces, children live and chipping away at the road, in strife with the law, kid outcasts, isolated kids without their families, kids in spots of contention and catastrophic events, marginalized sexual minority, kids living in ghettos and the offspring of sex workers. Children who have a place with a few of these gatherings are much more helpless. The sampling method is simple random because to find such children. A semi structured interview schedule was prepared before interviews.
\end{abstract}

Keywords: Children, sex workers, child abuse, poverty, juvenile justice

\section{Introduction}

It's better to be on roads than in homes because in the home I am more frustrated due to the violence by my father.

\section{Mr. NO Interview from field data}

I am not a childanymore, I saw the world from a very different perspective actually I am more mature than any adult,

Ms. ZB Interview from field data

The question arises here that what is the definition of child. Often in the socio-cultural backgrounds childhood defined the childhood or adolescence; although all countries have ratified the CRC the situation is different from the picture. From early age girls and boys often forced to act like adults. * Aliyah Ali Bilgrami, Ph.D., Assistant Professor, Centre of Excellence for Women's Studies, University of
Karachi 
It is difficult to explain child prostitution because of the variations of perspectives it includes, legal, research, media, policy ${ }^{1}$. Child commercial sex workers explain well about their activities better than their clients and pimps explain or may speak more social activists, the police or social service providers to make strategies for eliminating the issue. Sexual commercial exploitation has been sometimes defined as child labor provisions because to change the shift from sex to exploitation, but all these definitions have limitations ${ }^{2}$. The terms usually used are sexual abuse of child and child prostitution are very different from the terms "Abuse" and "Prostitution", the last being viewed on commercial exchange. Sexual abuse of child is characterized as contacts or communications involving a child with a mature person or a grown-up, and the kid had used as an object for the other individual's sexual movement. Although the child is unwilling for these communications, rewards, dangers or weight. On the contrary, "Sexual abuse of child or prostitution of child "defined as the exploitation of a kid for sexual intention to deal or out of the way favors between clients, middle person or specialist or other people who get benefit from the exchange of these children ${ }^{3}$.

Sexual commercial abuse of minors or minors sex trafficking characterizes by the Institute of Medicine as "a scope of misconduct of a sexual sort conferred against children and youngsters, including (1) enlisting, alluring, harboring, transporting, giving, acquiring, as well as keeping up (acts that constitute trafficking) a minor with the objective of sexual misuse; (2) misusing a minor through prostitution; (3) exploiting a minor through survival sex (trading sex/sexual represents cash or something of significant worth, for example, safe house, sustenance or medications); (4) utilizing a minor in erotic entertainment; (5) misusing a minor through sex tourism, and early marriage; and (6) abusing a minor by having her/him perform in sexual scenes (e.g., peep shows or strip clubs) ${ }^{4}$. For the motivations behind this report, this definition will be marked "sexual commercial abuse of children", or CSEC.

Usually, it implies a pimp who has the control over or supervises the child's activities and advantages from commercial exchanges in which the child is made accessible for sexual purposes. The prostitution of youngsters is frequently sorted out in conditions, for example, massage parlors, bars, clubs, and inns, however, it additionally happens in private homes and in the city. Bessell (2007) found that kid assurance got no consideration from policymakers as of not long ago and Child Protection Law No. 23/2002 had been implemented in 2002. ${ }^{5}$ In South Asian countries the conditions are not different. Though it is critical, to comprehend the explicit condition of teenagers as well

\footnotetext{
${ }^{1}$ Kelly, L., R. Wingfield, S. Burton and L. Regan. Splintered Lives: Sexual Exploitation of Children in the Context of Children's Rights and Child Protection, Barnados, Essex, (1995).

${ }^{2}$ Ibid.

${ }^{3}$ United Nations Economic and Social Commission for Asia and the Pacific (UNECAP) Sexually Abused and Sexually Exploited Child and Youth in South Asia: A Qualitative Assessment of their Health Needs and Available Services, (United Nations, New York, 1999).

${ }^{4}$ IOM (Institute of Medicine) and NRC (National Research Council). Confronting sexual commercial exploitation and sex trafficking of minors in the United States. (Washington, DC: The National Academies Press, 2013); 2.

${ }^{5}$ Sharon Bessell, "Children, Welfare and Protection: A New Policy Framework?" in Indonesia: Democracy and the Promise of Good Governance, ed. Ross H. McLeod and Andrew J. MacIntyre, (Singapore: Institute of Southeast Asian Studies, 2007); 138-156.
} 
as its regular connection through needs and broken family unit. "Survival sex" underlines the sexual commercial abuse of adolescents to fulfill the needs of life to get food, narcotics, clothes, transportation, or money to buy these goods and enterprises. Some investigations announced that teenagers had not considered their commercial sexual activities like sex work or prostitution ${ }^{6,7,8}$. Survival sex does not represent every one of the reasons youngsters might be associated with sexual commercial activities, including sexual touch, intimated concern, cash, drinks, and other benefits ${ }^{9}$. Some exploitation of children includes the utilization like a product for sale between grown-ups sexually. Boundaries are blurred among prostitution of child, pornography and abuse. Children in a significant number engaged with business sexual actions are recognized to have been sexual exploitation ${ }^{10}$.

We characterize prostitution of child to incorporate circumstances when a youngster has taken cash or else products from the culprit party previously or later than sex, in any age children are liable to prostitution ${ }^{11}$. Jeffreys (1997) keeps up that for the powerless and frequently misled youngster, there might be few or no elective alternatives. Unfortunately, children may regularly persuade themselves that they have settled on a free decision, instead of recognizing that they have lost control over their own lives ${ }^{12}$.

Sri Lanka (focusing most on children issues and liberal way of dealing with kinship) in South Asiancountrieswas principal nation to formally perceive child abuse. Early instances of physical abuse as indicated by De Silva (2007), in the late 1980s showed up, in any case, sexual violence of child had archived while right on time as in $1940 \mathrm{~s}^{13}$. Similarly, according to De Zoysa (2002) by 1965, Sri Lanka's Sexually Transmitted Disease Control program showed the presence of an informal system engaged with the sexual commercial exploitation of boys. Additionally, specialists had additionally recorded that child sex is a major reason for tourism in Sri Lanka. In the 1990s, the Government of Sri Lanka made different strides, for example, Penal Code modification and the National Child Protection Authority establishment to manage the concern ${ }^{14}$. In the late 1970s from India, specialists (for the most part, pediatricians) consider abducting, the assault of kids and abuse of abandoned adolescents physically. In India child labor is a theme of enthusiasm for stipulations of adolescents' protection and welfare which

\footnotetext{
${ }^{6}$ Ferguson, S. Between a Rock and a Hard Place: Young People and Opportunistic Prostitution in Fortitude Valley and Brisbane City, (Brisbane Youth Service, 1993).

${ }^{7}$ Hancock, L. Young People Involved in Prostitution in Victoria, (Australia: Deakin University, Geelong, 1994).

${ }^{8}$ Stewart, K. Opportunistic Prostitution and Young people in Cairns City and Mulgrave Shire, (Queensland: Youth Services, 1994)

${ }^{9}$ Tschirren, R., K. Hammet and P. Saunders. Sex for Favours: The On the Job Youth Project: The Definitive Report, (Adelaide: Sex Industry Network, 1996).

${ }^{10}$ Giobbe, E. "Confronting the liberal lies about prostitution" in D. Leidholdt and J.R.Raymond (eds.) The Sexual Liberals and the Attack on Feminism, (New York: Pergamon Press, 1990)

${ }^{11}$ Saphira, M. The Commercial Exploitation of Children, (Auckland: ECPAT, 2001).

${ }^{12}$ Jeffreys, S. The Idea of Prostitution, (Melbourne: Spinifex, 1997)

${ }^{13}$ De Silva D.G.H (2007) Children needing protection: experience from South Asia. Archives in Diseases in Childhood, 92,931-934 doi: 10.1136adc.2006.101196 http://adc.bmj.com/content/92/10/931

${ }^{14}$ Piyanjali De Zoysa, "Sexual abuse of children Sri Lanka: the Current State of Affairs and Recommendations for the Future," Sexual abuse of child11, no. 2 (2002): 97-113.
} 
secured diverse children security problems including abuse sexually and physical and psychological exploitation ${ }^{15}$.

\section{Research Question}

The study has been conducted to analyze the reasons of child sex workers and its impact on their personalities. The psychological trauma in which they are living continuously and physical abuse they are suffering from is difficult to measure or count in words but the study try to explore these aspects of child sex workers.

\section{Theoretical Framework}

Robert Merton (1938) offered the strain theory, which endeavored to clarify social class differences. Merton saw that, in the United States, the social ethos of the "American Dream" empowers all people, paying little attention to condition, to take a attempt at individual achievement, with an stress on the collection of money related materials. In the meantime, nonetheless, open doors for making money related progress are appropriated unevenly in the public arena. As Merton perceived, unavoidable disparities in the United States make genuine obstructions to progress for some, lower-class people. This specific arrangement of culture (the socially recommended objective of financial issues) and social structure (disparity of chance) is said to produce strain. Specifically, huge sections of the populace disguise the American Dream ethos however come up short on the lawful or real intends to achieve financial riches, which adds to objective blockage and dissatisfaction. ${ }^{16}$ Although attachment theory scholars believe that people create practices because of how their guardians sustain them. As per connection hypothesis, the kind of bond that creates among youngster and parental figure influences the kid's later connections ${ }^{17}$. Child abuse historically believes that victim child is damaged by trauma though; intensity of abuse, frequency of abuse, age of the victim, and relationship to the perpetrator can predict later adjustment. As well, social support, parental affection, and the victim's healthy relationship with a supportive adult can influence the child's healthy development and avoidance of delinquent behavior. Resiliency does not explain why abuse and neglect occur, rather, it explains why children may not inevitably be damaged by child abuse and neglect. It may also explain how the "cycle of violence" can be interrupted $^{18}$.

\section{Literature Review}

Children in this trade are in severe danger ${ }^{19}$. Upwards of 326,000 US kids are in danger for CSEC every year ${ }^{20}$ according to Estes and associates. There is an absence of

\footnotetext{
${ }^{15}$ Study on Child Abuse: INDIA 2007 Ministry of Women and Child Development, Government of India,https://www.childlineindia.org.in/pdf/MWCD-Child-Abuse-Report.pdf

${ }^{16}$ Merton, R. K. (1938). 'Social Structure and Anomie.' American Sociological Review, 3, 672-682.

${ }^{17}$ Bacon, H., \& Richardson, S. (2001). Attachment theory and child abuse: An overview of the literature for practitioners. Child Abuse Review, 10(6), 377-397.

${ }^{18}$ Child Abuse Intervention," The National Institute of Justice, OJP, USDOJ, October 3, 1997

${ }^{19}$ Stansky, M., \& Finkelhor, D. How many juveniles are involved in prostitution in the U.S.? (2008), Accessed

at \#http://www.unh.edu/ccrc/prostitution/Juvenile Prostitution factsheet.pdf
} 
quantitative companion character of sexual commercial abuse of child in America exhibiting for therapeutic care. Comprehensive Family Assessment (CFA) in the course of the most recent decade is become the top follow in welfare of child. Extensive Assessments of family go past hazard evaluation for building up a whole photo of the youngster's and family's circumstances which prompted the present conditions and which can drive benefit arrangement ${ }^{21}$. The objective of leading an appraisal is to give a photo which is wide and top to bottom, investigating various components which may add to hazard and fortify prosperity. Expansiveness is portrayed by the examination of the formative and conduct needs and in addition the working and needs of individuals and frameworks associated with the teenager's life as guardians, kin, more far-away family, network, and school. Understanding is comprehended as looking at the past or time and issues or the connections idea, which counteract or bolster prosperity. General population lifts up and cooperating to the youth is basic to sustaining wellbeing along with prosperity. These connections - particularly amongst parent and youngster yet in addition amid a blood relation and different grown-ups - are basic to understand the family and children needs ${ }^{22,23}$. This work directed as a feature of a helpful understanding (Grant number 90-CA-1752) between the Illinois Department. Developing and examining a structure to assess the nature of exhaustive family appraisal in child welfare.

What is clear is that once a youngster turns out to be effectively associated with sex work they confront a large group of dangers and troubles. The researches regarding child abuse focus to some regular subjects; youngsters taking an interest in sexual commercial activities are probably going to have escaped from poor households, these are powerless to hazardous sexual practices, and presented to narcotics and alcohol utilize and abuse ${ }^{24}$. There are various risks in adopting sex work, including assault, trap, burglary, snatching, customers demanding cash back after sex or declining to use contraceptives. It is viewed as more unsafe to take a shot at the lanes than in massage parlors ${ }^{25}$, or in city numerous children have started sex work. In any case, the passionate dangers and harm might be more noteworthy comparatively substantial. Researches and the declarations of victim children discuss damage that intense that frequently they are unfit to come back to an ordinary lifestyle ${ }^{26}$.

${ }^{20}$ Estes, R. J., \& Weiner, N. A. (2002). The Sexual Commercial Exploitation of Children in the US, Canada and Mexico. 2002. Center for the Study of Youth Policy, University of Pennsylvania. Available at \#http://www.sp2.upenn.edu/restes/CSEC Files/Complete CSEC 020220.pdf .

${ }^{21}$ Schene, P. Comprehensive Family Assessment Guidelines for Child Welfare. (NY: National Resource Center for Family-Center Practice and Permanency Planning, 2005)

${ }^{22}$ Budd, K. S. Assessing Parenting Capacity in a Child Welfare Context. Children and Youth Services Review, (2005), 27, 429-444.

${ }^{23}$ Johnson, Cathryn, Timothy J. Dowd and Cecilia L. Ridgeway. Legitimacy as a Social Process Annual Review of Sociology, (2006), 32: 53-78

Johnson, Cathryn, Timothy J. Dowd and Cecilia L. Ridgeway. "Legitimacy as a Social Process" Annual Review of Sociology, (2006), 32: 53-78.

${ }^{24}$ Fitzgerald, P. Bridging the Gap. Melbourne: ECPAT (Australia Inc. 1997)

${ }^{25}$ Plumridge, L., and G. Abel, (2001) "A 'segmented 'Sexual Industry in New Zealand: Sexual and Personal

Safety of Female Sex Workers" Australian and New Zealand Journal of Public Health, 25(1):78-83. [s]

${ }^{26}$ International Labour Organization (ILO),

1999https://www.ilo.org/dyn/normlex/en/f?p=NORMLEXPUB:12100:0::NO::P12100_ILO_CODE:C182 
Philip Aries as per the French history expert, concept of adolescence had not existed in the culture of medieval Europe as "no attention was given to kids, their specific character, which recognizes children separately from adults ".But the situation is not same in the world's different parts. Breaking down many composed sources including from beginning of Islam to the sixteenth century dissertations, books, chapters from books and juridical writing, as Anver Giladi (1989) exhibited the Muslim human progress had prosperous and differentiated information regarding the bodily progression of children, the analysis and treatment of youth disorder and psychology of adolescents .As Giladi (1989) noticed that raising practices of children in medieval Islamic social orders, uncovered a more noteworthy worry about kids in comparison with in early European social orders as recognized by Philipp Aries ${ }^{27}$.

In any case, the abuse of kids has dependably happened all through the history and crosswise over cultures. Child protection initially turned into an open worry in social orders of the worldwide, in the late nineteenth century north where youngsters were initially observed as immeasurable (as far as their passionate esteem) and defenseless (because of their maturity, mass and quality) and the innovative concept of youth in light of the enthusiastic view of children took shape. This worry was communicated as endeavors to lessen mortality of newborn and adolescents, child labor laws and obligatory instruction for children. Significantly, the move was made to ensure to establish Societies to Prevent Brutality against Children globally including the England in 1883and United States of America in $1871^{28}$. Instances of child abuse have been set up all through the worldwide. Along with the foundation of kids insurance benefits, historically advancement of protection for abuse have likewise been recorded in the worldwide North (as appeared in the sources referred to above).

Within correlation, the cutting edge child abuse history and insurance worldwide. Children security activities increased genuinely in 1989 following United Nations Convention on the Rights of the Child (UNCRC) reception. Similarly, number of periodical articles from less developed nations is on consistent increase which was noticed by Lachman (2002) regarding abuse of child and negligence somewhere in the range of 1992 and $2002^{29}$.

\section{Asia}

The world's most populated area is Asia; As Amartya Sen research(1990) showed that majority of women were misplaced from recorded information moreover recounts an unpleasant tale of imbalance with abandon ${ }^{30}$. As Coale (1991) refined the argument by Sen determining in certain Asian social orders the number of missing females and concerned view for particularly high sex ratio during childbirth and high female death

\footnotetext{
${ }^{27}$ Anver Giladi, "Concepts of Childhood and Attitudes towards Children in Mediaeval Islam," Journal of the Social and Economic History of the Orient 32 (1989): 121-52.

${ }^{28}$ Saphira, Miriam; Oliver, Pam A Review of Literature on Child Prostitution | Social Policy Journal of New Zealand, December 2002

${ }^{29}$ Peter Lachman et al., "Challenges Facing Child Protection," Child Abuse \& Neglect 26, no. 6-7 (2002): $587-$ 617

${ }^{30}$ Amartya Sen, "More than 100 Million Women are Missing," New York Review of Books, 20 December 1990.
} 
rates in the premature birth. Research proposed that "missing women" of Sen and "missing females" of Coale had really "lost adolescent girls" and clarified unreasonable before birth female mortality, during childbirth, initial life and adolescence. ${ }^{31}$

The protection of abandon children in China is an important problem of society. The number of neglected Chinese kids since the 1980s is rising pointedly, and increases to the interest for official organizational concern. Haditono (1981) recorded different types of child abuse, disregard, and misuse, in any case, noticed that absence of laws (proportionate to) kids security mechanism of country ${ }^{32}$. Sexual commercial abuse of children is such an extraordinary violation and severe abuse of intensity applied over a child that it ought to be viewed as a terrible violent incident. These illegal activities are shown as prostitution of child, child sex tourism, pornography of children, and child trafficking for sexual purpose. They may likewise incorporate relational unions where compensation to contact to children as a sexual subordinate is included. The sum of its structures, sexual commercial abuse of children is a sign of intensity, eagerness, and brutal that speaks to a renouncement of rules that perceive the essential dignity of every individual.

A child is characterized by the UN Convention on the Rights of the Child (CRC) as any person younger than eighteen years. In any case, the absence of basic adherence to this definition in the lawful and administrative systems of numerous countries makes a hole that bargains the security of kids. Fluctuations in legitimate definitions give the space to individuals with a sexual interest for children to legitimize abuse in light of the fact that a child entrance to adulthood is resolved in respect to various social or social variables, and also contrasts at the beginning of physical development, as a rule, related with adolescence. Research directed by ECPAT International (End Child Prostitution, Child Pornography, and Trafficking of Children for Sexual Purposes) (2005a) ${ }^{33}$ and ILOIPEC (2006) on measurements of interest for sex with youngsters exhibit that such ideas carefully shape the impression of exploiters and others in the public arena, including kids and youths ${ }^{34}$. They make difficult and logical inconsistencies in how individuals conceptualize kids' rights and their requirement for assurance, which can bring about implied acknowledgment and resistance of the nearness of children in commercial sex, despite the fact that enactment, may exist to criminalize such practices. Interest for sex with children supports and fills a chain of wrongdoing and benefit that guarantees its propagation. Despite the fact to measure number of sexually abused kids is very difficult because of the secret idea of the violations, ILO (2002) ${ }^{35}$ assessed that there are exactly

\footnotetext{
${ }^{31}$ Ansley Coale, “'Excess Female Mortality and the Balance of Sexes in the Population: An Estimated Number of Missing Females," Population and Development Review 17, no. 3 (1991): 517-23.

${ }^{32}$ Haditono, S. Prevention and Treatment of Child Abuse and Neglect Among children under five years of age in Indonesia. Child Abuse and Neglect: The International Journal, 1981 5(2): 97-101

${ }^{33}$ Combating Child Sex Tourism: QUESTIONS \& ANSWERS, ECPAT International (End Child Prostitution, Child Pornography and Trafficking of Children for Sexual Purposes) 2008

${ }^{34} \mathrm{www}$. ilo.org/ipecinfo/product/download.do?type=document\&id=772

${ }^{35}$ A FUTURE WITHOUT CHILD LABOUR INTERNATIONAL LABOUR CONFERENCE 90th Session 2002 https://www.ilo.org/ipecinfo/product/download.do?type=document\&id=2427
} 
1.2 million children has been trafficked worldwide consistently. Numerous are trafficked for commercial sex (ECPAT 2004) ${ }^{36}$.

\section{South Asia}

The South Asian countries of have an arrangement of local religious, societal, and lawful traditions related to youth. Regardless, all shows one factor which is foreswearing of adolescent abuse. Therefore authentic reports of ratio and consistency of child abuse are about missing; diverse bits of establishment in the year 1860 indicated the different sorts of child abuse, and to children's requirement in Indian sub-Continent for security.

Sex workers on streets were identifies as street -based sex workers. Child welfare laws targeted child sex workers were often baffled in the situation where parents' sex work increases the ratio of child sex work and abuse. These child sex workers were available everywhere in public places e.g. streets, shopping malls, parking lots or in private places in hotels, hostels or in homes Servicing clients in outdoor due to violence, lower economic conditions lack of housing and unavailability of social protection which increase the risk of child fears. Lack of governmental child support services increases the vulnerabilities of family and children in every aspect. It drives women to get in to more poverty and force them to do prostitution. It shows the flaws public service system. ${ }^{37}$

\section{Pakistan}

In Pakistan, one cannot deny the reality that historical backdrop of abuse of child and security problems began in 1947 with the origin of nation. No kids precise authentic records are accessible, yet, it is deep-rooted a reality that adolescents were victim of the savagery at the time of partition. From that point onward, children in Pakistan have been casualties of battle for instance 1971 war), as natural disasters (floods and earth quakes) and national migration because of rough clashes in their regions.

Generally, the most precise gathering and distribution of information on children security issues have been that in the mid-1990s on child work and in the late 1990s on kid sexual abuse. As the1996national child labor survey, 8.3 percent (3.3 million) of all kids populace matured 5-14 years of monetarily dynamic children was observed. Although, child labor is being for some time recognized and broadly considered and discussed in Pakistan, it was not acknowledged protection issue of children up to this point. Child labor is a security subject began through progressive acknowledgment for circumstance of kids within dangerous professions, for example, children local labor, bonded labor or for Gulf States child trafficking is common for camel racing. ${ }^{38}$

Sexual abuse of adolescents and misuse is even complicated. For example the "Pakistan Suppression of Prostitution Ordinance 1961 (which prohibit the attraction, attention by

\footnotetext{
${ }^{36}$ Combating Child Sex Tourism: QUESTIONS \& ANSWERS http://www.ecpat.org/wpcontent/uploads/legacy/cst_faq_eng.pdf

${ }^{37}$ www.plosone.org 3 June 2014 | Volume 9 | Issue 6 | e99664 Aboriginal discrimination against girl children

${ }^{38}$ Tahira Jabeen A History of Contemporary Child Protection in the Global South (WITH A SPECIAL FOCUS ON SOUTH ASIA AND PAKISTAN) J.R.S.P., Vol. 50, No. 1, 2013]
} 
words, gestures, willful and indecent exposure of the body for the purpose of prostitution of a girl less than 16 years of age)" demonstrate presence of the issue. In any case, conventional frames of mind identified with "virtuousness" and "family respect" makes it troublesome for cases to be accounted for, particularly in a girl child, "society and even her own family and friends rejected her". NGOs reported that taking a shot at child sexual exploitation and abuse, be that as it may, show higher percentage. SAHIL, a nongovernment association, functioning for the child abuse, had been recorded 2303 instances of abuse of child (police affirmed paper information) in the year 2011in the nation.

Interestingly, acknowledgment of some other children security issues was dramatic, even emotional. For instance, 100 children were killed by a serial killer in Lahore, Pakistan in 1999, the protection of impoverished, run away, street and neglected children become a standout amongst the most issues of child protection in Pakistan. This scene additionally featured the issue of brutality against youngsters, particularly the utilization of flogging as a penalizing method in different conditions as household, educational institute, and environment at work place, which made children run off from these places and stop in the city toward the sufferers of a serial killer ${ }^{39}$.

\section{Research Methodology}

This study has a qualitative approach. The participants of the study were interviewed initially to gather socio-demographic characteristics (name, ethnicity, religion, qualification and parents' profession and address). The second stage was to know the reasons of their victimization as child sex workers. The sampling method is simple random because to find such children who were prepared to give details were difficult, therefore the research criteria was based on whoever and wherever we find. Fifteen children below eighteen were interviewed in detail. Case studies of six boys and nine girls were collected through a semi structured interview schedule, prepared before interviews.

\section{The Procedure of Data Collection}

The data has been collected from children from different areas of Karachi. The respondents were interviewed in-depth. The children were shared their feelings and experiences about being working as commercial sex workers.

\section{Data Analysis Procedure}

Building on the statements and quotations recoded from the respondents against the central research questions, the significant statements, sentences and quotes were highlighted which provided a better understanding of children lives.

\footnotetext{
${ }^{39} \mathrm{Ibid}$.
} 


\section{Results and Analysis}

\section{Case Study No. 1}

Shahnaz is sixteen years of age. Her mother was a beggar. On our first meeting she felt hesitation in discussing about her life. She thought that maybe that researcher belong from any law enforcement agency that's why she was very reserved first but in second meeting she was relaxed and told many things about her life style. She said that due to poverty she is forced to do that work, moreover she was not happy with it but her mother forced her by emotional blackmailing. On further inquiry she told that at the age of seven she started selling flowers on traffic signals but after some months she was abused sexually by a Rickshaw driver. When she told about the incident to her mother than she said carelessly

to kya huva aisa to hota hay hum sarkon par rehnay walay hen kisi seth ki aulad nahi adat daal lay" (No big deal actually, we are living on roads, you are not kin of any rich person you have to be habitual of it).

Child abuse incorporates current situation analysis or evaluations of different child protection issues, for example, those identifying with the camel racers, the sexual commercial abuse and juvenile justice for kids. Moreover, Pakistani children, particularly female children, are likewise exposed to hurtful conventional practices, for example, vanis/swara (the trading of females in compensation for debt), forced as well as child marriages and honor killings, be that as it may, with no historical documented evidence, occurrence, and commonness about specific problems. UNICEF, in the 2000-09 periods indicated that, 16 percent of urban and 29 percent of provincial Pakistani women between the age group of 20 and 24 years had been married before the age of 18 years ${ }^{40}$.

This shows the cruel face of poverty in Pakistan. The most routinely perceived push factor driving the trafficking procedure is poverty ${ }^{41}$. Shahnaz also informed that she is scared of people around her and saw strange dreams during sleep. She spoke a few English words which she learned from surroundings. She also said that she wanted to go to school but due to low economic conditions she could not get education.

\section{Case Study No. 2}

Shahzad was seventeen years old. He looked very confident and shared information in detail. First he asked why you come at that time

"Yeh to hamaray dhanday ka time hay" (this is our business time).

He wore clean clothes and said I like to be neat and clean. On asking further question he laughed and told the researcher that I chose this way willingly because I wanted a luxurious life style which my parents can't afford. He said that his father wanted him to get education and be a rich man but

${ }^{40}$ Ibid. 
Insaan kay pas paisa bhi to hona chahiye achi taleem kay liye

(We should have enough money for good education).

He informed the researcher that he never suffered from any psychological issue Why he asked I had money which I enjoyed so why I feel bad?

While no youngster is absolved from the danger of sexual abuse and misuse, a few gatherings of kids are vulnerable than others. Which incorporate physically and mentally handicap kids, youngsters from racial groups and minimized populaces, kids live and chipping away at the road, youngsters in strife with the law, kid outcasts, kids isolated from their families, kids in spots of contention and catastrophic event, kids live in ghettos or offspring of prostitute. Kids who contain a place with a few of these gatherings are much more helpless ${ }^{42}$.

\section{Case Study No. 3}

Zahida was seventeen years of age. She was tall and fair. She said that she was getting education from a street school. She told the researcher that she wanted to become a doctor because her father was very sick. Her mother was a domestic worker and she had seven siblings. Due to poverty she had told to do the sex work by her friend. She said that we were not save either on roads or in homes. She dreamt on many things like becoming a doctor or marriage to a respectable man but knew very well that her dreams are only dreams.

Rising destitution is driving a developing figure of family units to offer kids, with young girls specifically get involved in sex work. "We have an ever increasing number of reports of individuals selling their children because of hunger," according to I.A. Rehman, secretary-general of the Human Rights Commission of Pakistan (HRCP) ${ }^{43}$. He said that teenage children were trafficked outside the nation, and teenage girls were, for the most part, trade for sex exchange. As per HRCP, increasing joblessness is a major factor adding to needs. As per independent researches, 15.2 percent is the rate of unemployment ${ }^{44}$. According to International Labor Organization human trafficking is obscure, that 20.9 million individuals are sufferers of forced work far and wide according to the. This approximation incorporates sex trafficking and sufferers of work. Of this gigantic gathering, roughly 4.5 million individuals are sufferers of strained sexual abuse, as well as around 945,000 children (International Labor Organization, 2012) ${ }^{45}$

They may likewise be undermined in return for higher school grades, additional pocket money, or merchandise. In all cases, youngsters abused in prostitution are captured by complex social conditions that make them defenseless against operators who perceive

\footnotetext{
${ }^{42}$ Save the Children Alliance, 2005, '10 Essential Learning Points: Listen and Speak out Against Sexual Abuse of Girls and Boys' (global Submission to the UN Study on Violence Against Children)

${ }^{43}$ State of Human Rights in 2005 , Human Rights Commission of Pakistan, Karachi, 2006

${ }^{44}$ Ibid.

${ }^{45}$ International Labor Organization (ILO). (2012). Global estimate of forced labour: Executive Summary. Available at: \#http://www.ilo.org/wcmsp5/groups/public/— ed norm/declaration/documents/publication/wcms 181953.pdf (accessed Dec 23, 2014).
} 
and misuse these vulnerabilities. Earlier violence or sexual abuse tolerate in their prompt condition is a typical case of conditions that can prompt the prostitution of children. False impressions about the expression "child prostitution" have provoked utilization of the expression "sexual commercial abuse of children," as the latter is an also including a depiction of the full extent of sexual violation against children. As well as "child prostitution" conveys hazardous implications that can bring about accusing the casualties of these violations. These violations make it obvious that children can't be agreed on a decision to prostitute themselves, as the demonstration of discouragement the kid, in each incident, is in certainty did by another gathering. Albeit universal law unmistakably sets up that the component of decision does not have any significant bearing to any type of grown-up sexual act with a child, references to "child prostitution ," especially on account of juvenile children, regularly convey negative undertones that invalidate the children's involvement of power, misuse, and physical and mental harm happened through their incarceration in prostitution. Nonetheless, in connection to children, reference to "sex work" is entirely deceptive and hurtful, as it makes light of the illicit abuse of the children and can recommend that teenagers has by one means or another settled on a decision to take after a "calling" in "sex work." This is a basis that exploiters regularly utilize. The understanding of child abuse is easily developing after seeing these facts that children are commenced, deceived and threatened by vulnerabilities that others adventure to prostitute them ${ }^{46}$.

\section{Conclusions}

This analysis has shown that abuse of child has been going on in the South Asian Countries since long. Many researches show the existence of different kinds of child mistreatment. The role of Government is not playing a sufficient role in preventing commercial child sex work. Moreover poverty, high inflation and in country migration are the major factors contributing in child sex work. These abuses can be eliminated through children related social conventions, including assurance of child, pharmaceutical, legislation, public advancement, or brain research.

${ }^{46}$ The World of Child Labor. Hugh D. Hindman(Ed.) (Rutledge: New York, 2015) 